Original Research Paper

\title{
Current State of Haplic Chernozems in Specially Protected Natural Areas of the Steppe Zone
}

\author{
${ }^{1}$ Saglara S. Mandzhieva, ${ }^{1}$ Lyudmila Yu. Goncharova, ${ }^{2}$ Abdulmalik A. Batukaev, \\ ${ }^{1}$ Tatiana M. Minkina, ${ }^{1}$ Tatiana V. Bauer, ${ }^{1}$ Aleksey K. Shertnev, ${ }^{1}$ Victor A. Chaplygin, \\ ${ }^{1}$ Svetlana N. Sushkova, ${ }^{3}$ Evgeny V. Poluektov, ${ }^{1}$ Marina V. Burachevskaya and ${ }^{1}$ Marina N. Kozlova \\ ${ }^{1}$ Southern Federal University, Rostov-on-Don, Russia \\ ${ }^{2}$ Chechen State University, Grozny, Russia \\ ${ }^{3}$ Novocherkassk Reclamation Engineering Institute, Novocherkassk, Russia
}

Article history

Received: 11-08-2017

Revised: 17-08-2017

Accepted: 13-12-2017

Corresponding Author: Saglara S. Mandzhieva Southern Federal University, 194/1 Stachki prosp., Rostovon-Don, 344090, Russia Tel: +7-988-896-95-53 Email: msaglara@mail.ru

\begin{abstract}
The current ecological state of Haplic Chernozems has been studied in three Specially Protected Natural Areas (SPNAs) of the Steppe zone in South of Russia. It has been found that the content of organic matter, texture and elements content of soils depend on the period and conditions of reservation in the SPNA. In accordance with the content and reserve of organic matter, the thickness of the humus-accumulative (A) and humus $(\mathrm{A}+\mathrm{B})$ horizons and the supply with macro- and micronutrients, the Haplic Chernozems of the SPNAs under study can be arranged in the following series: Persianovskaya Reserved Steppe $>$ Botanical Garden of the Southern Federal University > Reserved Fallow land "Priazovskaya Steppe", which corresponds to the duration of their reservation periods. The Botanical Garden, which is located in the center of a megalopolis (Rostovon-Don, Russia), has higher contents of lead in the upper horizon of Haplic Chernozem than other soils on the plots considered.
\end{abstract}

Keywords: Chernozems, Specially Protected Natural Areas, Heavy Metals, Organic Matter, Soil Morphology

\section{Introduction}

The monitoring of soil degradation requires comparing with natural analogues or standard zones to the minimum extent modified by anthropogenic factors. The soils of the specially protected natural areas can serve as such analogues (Ervin, 2003; Cantu-Salazar et al., 2013). One of the most efficient ways of restoring and preserving the natural ecosystems is to create a scientifically based system of Specially Protected Natural Areas (SPNAs) comprising typical and unique landscapes; habitats of economically valuable, rare and engendered plant and animal species; and standard natural zones with remained primary plant communities (Buzmakov and Sannikov, 2014; Gaston et al., 2006; 2008; UNLPA, 1998; 2003).

The SPNAs include lands, water bodies and the atmosphere; they contain natural complexes and objects of special conservation, scientific, cultural, esthetic, recreation and health-recreation value, which were completely or partially excluded from economic use by the decision of state authorities and for which special protection conditions were established (SPNA, 1995). All the SPNAs in Russia can be classified depending on the state of reservation into three groups.

\section{Full Reservation}

These conditions are established for nature reserves and natural monuments. They exclude economic activity in the area. Human intervention is permissible only in exceptional cases: For scientific research, sanitary felling, fire control, predator control, etc.

\section{Partial Reservation}

This is a combination of total prohibition and limited economic activity (exploitation of natural resources). These conditions are established in partial reserves.

\section{Mixed Regime}

This is a combination of reserved areas with those used for recreation and tourism, which is applied at the organization of national and natural parks. 
Natural monuments are separate unique natural objects and complexes of ecological, scientific, historical-cultural, esthetic and environmentaleducation value needing special state protection. The main aim of the organization of natural monuments is to preserve their objects and complexes in their natural state (SPNA, 1995).

Along with the natural monuments, the following categories of SPNAs in Russia are identified with consideration for their protection features, status and environmental institutions in their areas: State natural reserves (including biosphere reserves), national parks, natural parks, state partial reserves, arboretums and botanical gardens and health recreation localities and sanitariums.

The Lower Don basin plays an important role in the economics of Southern Russia; this is a large producer of agricultural products and a developed industrial region. Chernozems are the main soil types in the Lower Don basin; they occupy almost $65 \%$ of the total land area. The unique steppe biogeocenoses with rich flora and fauna are almost completely plowed up and may be considered as almost totally lost because of their intensive use. They partially remain only on nonarable lands and in forest belts.

The aim of this work was to study the current ecological state of Haplic Chernozems in the SPNAs of the Lower Don basin (South of Russia).

\section{Materials and Methods}

\section{Site Description}

The Lower Don basin represents a steppe area at the South of Russia. A vast area in the Lower Don basin is occupied by Rostov region (Valkov et al., 1982). The region has a favorable moderately continental climate. The mean air temperature is $-7^{\circ} \mathrm{C}$ in January and $+23^{\circ} \mathrm{C}$ in July. The sunshine duration is 2050-2150 hours per year. The mean annual precipitation is $242 \mathrm{~mm}$. It decreases from the west $(650 \mathrm{~mm})$ to the east $(400 \mathrm{~mm})$.

The objects of study included medium deep and deep calcareous Haplic Chernozems on loess-like loams in the SPNAs of the Lower Don basin:

- Botanical Garden of the Southern Federal University

- Persianovskaya Reserved Steppe

- Reserved Fallow land "Priazovskaya Steppe"

The locations of the SPNAs are shown in Fig. 1.

Botanical Garden of the Southern Federal University (area is $160.5 \mathrm{ha}$ ) is located within a megalopolis (Rostov-on-Don). The area is used for not only the accumulation and preservation of the unique genofond, but also the introduction of world and national plant species in the steppe zone. The Botanical Garden was created in 1927. In 2006 the Botanical Garden was included in the list of SPNAs as a state natural monument of local significance with mixed regime of reservation (Dobrovolskii and Nikitin, 2009).

Persianovskaya Reserved Steppe (area is $66 \mathrm{ha}$ ) is a unique massif of preserved virgin vegetation and the virgin soil cover of the Azov steppe with numerous rare and engendered steppe plants (Dobrovolskii and Nikitin, 2009). The reserve exists since the early 20th century; since 1990, it is a state natural monument of local significance with full reservation conditions.

Reserved Fallow land "Priazovskaya Steppe" (area is $15 \mathrm{ha}$ ) was organized for the restoration and preservation of unique natural objects in the steppe zone of the Rostov region. It exists as a fallow land with full reservation conditions since 1939 (Dobrovolskii and Nikitin, 2009).

\section{Soils}

The objects of study were Haplic Chernozems, ID 14-2 (IUSS, 2015), prevail in the soil cover of the Lower Don basin. The soil has a heavy loamy texture. The parent rocks of these soils predominantly consist of carbonate loess-like clays and loams, 6 to $50 \mathrm{~m}$ thick, of glaciofluvial, alluvial and alluvial-deluvial origin containing 4 to $17 \% \mathrm{CaCO}_{3}$. In these soils, $\mathrm{pH}$ is 7.3-7.7 in the upper horizons and 7.7-8.8 in the lower horizons.

The morphological profiles of Haplic Chernozems of the SPNAs are characterized by a humus horizon of medium thickness $(45-80 \mathrm{~cm})$ (Fig. 2). Effervescence is noted from the surface or in the lower humus horizon. Carbonate segregations primarily in the form of rare pseudomycelium appear slightly below the line of effervescence; their maximum content (beloglazka or "white eyes") is observed in the lower part of the transitional horizon Bca or BCca.

A typical morphological feature of Haplic Chernozem is the dark gray color of the humus horizons, which gradually changes to the brownish-pale colors of the lower horizons. The $\mathrm{A}$ and $\mathrm{AB}$ horizons are strongly penetrated by roots with abundant earthworm tunnels; they have a granular structure and gradual transition to the lower horizons. The $\mathrm{B}, \mathrm{BC}$ and $\mathrm{C}$ horizons are dark brown or brownish-pale in color and have medium subangular blocky or crumb structure.

\section{Sampling and Analysis of Soils}

Soil samples were taken from each soil horizon for studying the soil properties. Soil was homogenized, air dried and passed through a $1 \mathrm{~mm}$ sieve. The procedures of sampling and sample preparation to analysis were performed according to the standard methods (GOST 17.4.3.01, 1983). 


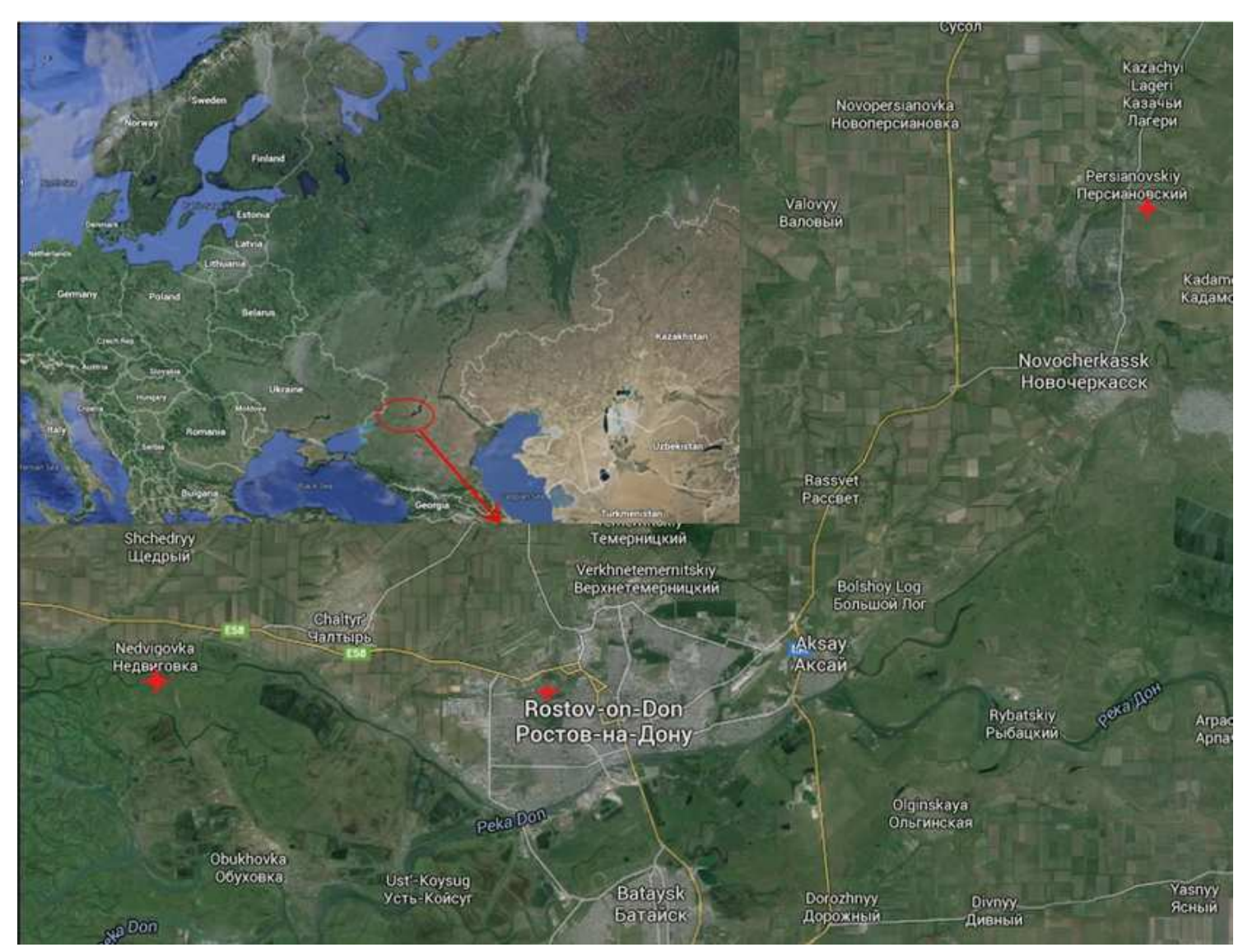

Fig. 1: The SPNAs in the lower don basin (South of Russia)

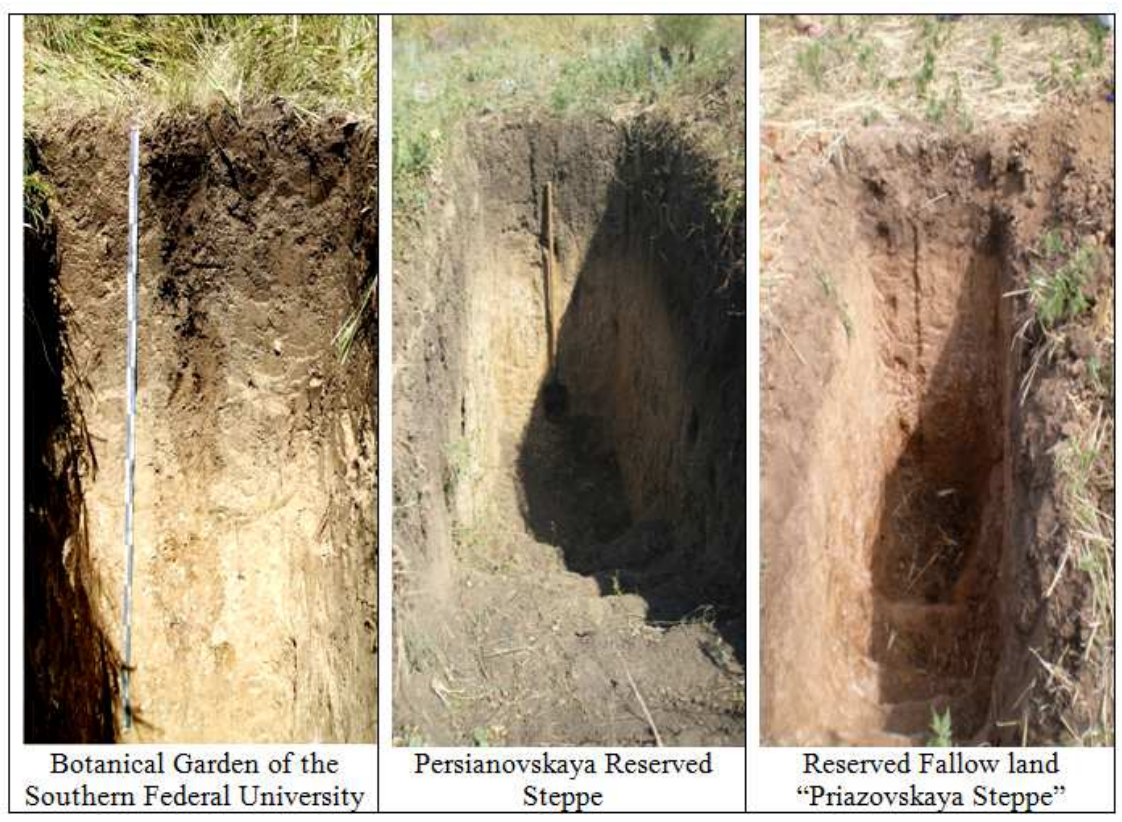

Fig. 2: Soil profiles of Haplic Chernozems in the studied SPNAs

Soil properties were analyzed using Russian standard methods (AMSS, 1990). Soil organic matter was determined by wet combustion with $\mathrm{K}_{2} \mathrm{Cr}_{2} \mathrm{O}_{7}$ and concentrated $\mathrm{H}_{2} \mathrm{SO}_{4}$ (the Tyurin method modified by 
Simakov) (Vorob'eva, 2006). This method is very close to the Walkey-Black method (1934).

Soil particle size distribution was determined by the pipette method after the pyrophosphate treatment (Vadyunina and Korchagina, 1973). Soil pH was measured with a pH electrode using a 1:5 suspension of a soil to water ratio. Carbonates were measured by the Kudrin method using $0.005 \mathrm{NH}_{2} \mathrm{SO}_{4}$ and then an excess of the acid was titrated with alkali (AMSS, 1990).

The reserve of organic matter in soil was calculated using the following formula (Orlov and Grishina, 1981):

$A=H \cdot V \cdot X$

where, $A$ is the reserve of organic matter, $\mathrm{kg} / \mathrm{ha}(\mathrm{t} / \mathrm{ha})$ in the soil layer of thickness $H, \mathrm{~cm} ; V$ is the soil density; and $X$ is the element content, $\%$.

The elements content of soil samples was determined by X-ray fluorescence analysis on a Spectroscan "Maks-GV".

\section{Statistical Analysis}

The results of chemical analysis correspond to the mean of three replicates. Descriptive data analysis, comprising minimum value, mean value, maximum value and standard deviation, was carried out with EXCEL 2010.

\section{Results}

According to the thickness of the humusaccumulative $(\mathrm{A})$ and humus $(\mathrm{A}+\mathrm{B})$ horizons (Table 1), the Haplic Chernozem of the Persianovskaya Reserved Steppe is classified as deep and the chernozems of Reserved Fallow land "Priazovskaya Steppe" and Botanical Garden as medium-deep. The Haplic Chernozems of the Reserved Fallow land "Priazovskaya Steppe" have the lowest thickness of the A and A+B horizons, which is their genetic feature (Dobrovolskii and Nikitin, 2009).

The highest contents of organic matter in the upper horizon (one of the essential soil parameters) was observed in the Haplic Chernozem of the Persianovskaya Reserved Steppe (Table 2 and 3), which corresponds to the medium level (Orlov et al., 2005; Minkina et al., $2017 \mathrm{~b}$ ). The chernozems of the Reserved Fallow land "Priazovskaya Steppe" and the Botanical Garden are characterized by low contents of organic matter.

Table 1: Morphometric parameters of Haplic Chernozems in the SPNAs of the lower don basin

\begin{tabular}{|c|c|c|c|c|}
\hline Haplic Chernozems & $\begin{array}{l}\text { The thickness of the } \\
\text { humus-accumulative } \\
\text { horizon }(\mathrm{A})(\mathrm{cm})\end{array}$ & $\begin{array}{l}\text { The thickness of the } \\
\text { humus horizon } \\
(\mathrm{A}+\mathrm{B})(\mathrm{cm})\end{array}$ & $\begin{array}{l}\text { The depth of } \\
\mathrm{CaCO}_{3} \\
\text { in soil }(\mathrm{cm})\end{array}$ & $\begin{array}{l}\text { The reserve of } \\
\text { organic matter in } \\
\text { horizon } \mathrm{A}(\mathrm{t} / \mathrm{ha})\end{array}$ \\
\hline $\begin{array}{l}\text { Botanical Garden of the } \\
\text { Southern Federal University }\end{array}$ & $31.0 \pm 2.6$ & $76.0 \pm 3.6$ & $75.0 \pm 8.1$ & $129.9 \pm 7.0$ \\
\hline Persianovskaya Reserved Steppe & $48.0 \pm 4.4$ & $90.0 \pm 6.5$ & $90.0 \pm 5.6$ & $280.8 \pm 10.5$ \\
\hline $\begin{array}{l}\text { Reserved Fallow land } \\
\text { "Priazovskaya Steppe" }\end{array}$ & $27.0 \pm 3.5$ & $52.0 \pm 4.0$ & $62.0 \pm 7.5$ & $137.2 \pm 8.0$ \\
\hline
\end{tabular}

Table 2: Physical and chemical properties of Haplic Chernozems in the SPNAs of the Lower Don

\begin{tabular}{|c|c|c|c|c|c|}
\hline \multirow[b]{2}{*}{ Horizon, dept $(\mathrm{cm})$} & \multirow[b]{2}{*}{$\operatorname{Corg}(\%)$} & \multirow[b]{2}{*}{$\mathrm{pH}$} & \multirow[b]{2}{*}{$\mathrm{CaCO}_{3}(\%)$} & \multicolumn{2}{|c|}{$\mathrm{CEC}(\mathrm{mM}(+) / 100 \mathrm{~g})$} \\
\hline & & & & $\mathrm{Ca}^{2+}$ & $\mathrm{Mg}^{2+}$ \\
\hline \multicolumn{6}{|c|}{ Botanical Garden of the Southern Federal University } \\
\hline $\mathrm{A}_{\mathrm{d}}, 0-10$ & $4.4 \pm 0.3$ & $7.5 \pm 0.3$ & $0.7 \pm 0.03$ & $35.5 \pm 2.4$ & $7.5 \pm 0.4$ \\
\hline A, $10-25$ & $4.1 \pm 0.2$ & $7.7 \pm 0.2$ & $1.9 \pm 0.02$ & $31.5 \pm 2.6$ & $6.8 \pm 0.3$ \\
\hline$A B, 25-60$ & $2.1 \pm 0.2$ & $7.7 \pm 0.2$ & $2.1 \pm 0.1$ & $27.5 \pm 1.6$ & $5.5 \pm 0.7$ \\
\hline $\mathrm{B}, 60-80$ & $1.5 \pm 0.2$ & $7.9 \pm 0.3$ & $3.3 \pm 0.3$ & $35.5 \pm 2.1$ & $6.5 \pm 0.3$ \\
\hline $\mathrm{BC}_{\mathrm{ca},}, 80-90$ & $0.2 \pm 0.01$ & $8.4 \pm 0.4$ & $9.8 \pm 0.4$ & $35.5 \pm 1.9$ & $5.5 \pm 0.4$ \\
\hline \multicolumn{6}{|c|}{ Persianovskaya Reserved Steppe } \\
\hline Ad, $0-20$ & $5.9 \pm 0.3$ & $7.5 \pm 0.2$ & $0.4 \pm 0.01$ & $34.4 \pm 2.9$ & $6.0 \pm 0.9$ \\
\hline A, $20-50$ & $5.0 \pm 0.2$ & $7.8 \pm 0.3$ & $0.9 \pm 0.03$ & $34.4 \pm 2.8$ & $7.0 \pm 0.7$ \\
\hline$A B, 50-75$ & $2.9 \pm 0.2$ & $8.2 \pm 0.3$ & $3.1 \pm 0.2$ & $28.8 \pm 2.0$ & $5.0 \pm 0.5$ \\
\hline$B, 75-90$ & $1.5 \pm 0.1$ & $8.6 \pm 0.4$ & $4.3 \pm 0.3$ & $23.2 \pm 1.9$ & $4.0 \pm 0.6$ \\
\hline BCca, 90-135 & $0.7 \pm 0.01$ & $8.8 \pm 0.4$ & $8.8 \pm 0.4$ & $26.0 \pm 1.6$ & $6.0 \pm 0.3$ \\
\hline \multicolumn{6}{|c|}{ Reserved Fallow land "Priazovskaya Steppe" } \\
\hline Ad, $0-11$ & $4.2 \pm 0.3$ & $7.7 \pm 0.1$ & $0.9 \pm 0.02$ & $37.2 \pm 3.5$ & $7.3 \pm 1.0$ \\
\hline A, $11-28$ & $3.8 \pm 0.3$ & $8.2 \pm 0.2$ & $2.3 \pm 0.1$ & $32.8 \pm 2.9$ & $9.3 \pm 0.8$ \\
\hline $\mathrm{AB}, 28-48$ & $2.1 \pm 0.1$ & $8.6 \pm 0.2$ & $3.5 \pm 0.3$ & $26.7 \pm 2.5$ & $6.9 \pm 0.6$ \\
\hline$B, 48-70$ & $1.7 \pm 0.2$ & $8.5 \pm 0.1$ & $8.0 \pm 0.6$ & $23.2 \pm 2.2$ & $6.1 \pm 0.5$ \\
\hline Bca,70-120 & $0.8 \pm 0.1$ & $8.7 \pm 0.2$ & $11.3 \pm 0.9$ & $25.8 \pm 1.9$ & $6.7 \pm 0.2$ \\
\hline
\end{tabular}


Table 3: The content of the organic matter in Haplic Chernozems in the SPNAs of the lower don basin during different periods of studies $(0-20 \mathrm{~cm}$ layer)

\begin{tabular}{llll}
\hline Year of research & $\begin{array}{l}\text { Botanical Garden of the } \\
\text { Southern Federal University }\end{array}$ & $\begin{array}{l}\text { Persianovskaya } \\
\text { Reserved Steppe }\end{array}$ & $\begin{array}{l}\text { Reserved Fallow land } \\
\text { "Priazovskaya Steppe" }\end{array}$ \\
\hline 1953 & $4.42 \pm 0.30$ & $5.15 \pm 0.38$ & $4.16 \pm 0.25$ \\
1983 & $4.10 \pm 0.25$ & $5.00 \pm 0.32$ & $4.11 \pm 0.20$ \\
2014 & $4.05 \pm 0.36$ & $5.08 \pm 0.26$ & $4.00 \pm 0.31$ \\
\hline
\end{tabular}

Table 4: Particle size distribution in Haplic Chernozems of the studied SPNAs

\begin{tabular}{|c|c|c|c|c|c|c|c|c|c|}
\hline \multirow[b]{2}{*}{ Horizon } & \multirow[b]{2}{*}{$\begin{array}{l}\text { Dept. } \\
\text { (cm) }\end{array}$} & \multicolumn{8}{|c|}{ Size fractions in $\mathrm{mm}$ and their content $(\%)$} \\
\hline & & $\begin{array}{l}1-0.25 \\
\text { large and } \\
\text { medium sand }\end{array}$ & $\begin{array}{l}0.25-0.05 \\
\text { small sand }\end{array}$ & $\begin{array}{l}0.05-0.01 \\
\text { large clay }\end{array}$ & $\begin{array}{l}0.01-0.005 \\
\text { mediumclay }\end{array}$ & $\begin{array}{l}0.005-0.001 \\
\text { small clay }\end{array}$ & $\begin{array}{l}<0.001 \\
\text { silt }\end{array}$ & $\begin{array}{l}<0.01 \\
\text { clay }\end{array}$ & $\begin{array}{l}>0.01 \\
\text { sand }\end{array}$ \\
\hline \multicolumn{10}{|c|}{ Botanical Garden of the Southern Federal University } \\
\hline$A_{d}$ & $0-10$ & 0.25 & 1.98 & 46.82 & 7.69 & 8.32 & 34.92 & 50.93 & 49.05 \\
\hline A & $10-25$ & 0.10 & 10.76 & 31.91 & 6.52 & 12.01 & 38.68 & 57.21 & 42.77 \\
\hline $\mathrm{AB}$ & $25-60$ & 0.01 & 1.69 & 42.98 & 8.57 & 10.90 & 35.83 & 55.30 & 44.68 \\
\hline $\mathrm{B}$ & $60-80$ & 0.16 & 13.00 & 28.33 & 3.89 & 18.02 & 36.58 & 58.49 & 41.49 \\
\hline $\mathrm{BC}$ & $80-95$ & 0.09 & 4.18 & 45.63 & 3.54 & 12.47 & 34.07 & 50.08 & 49.9 \\
\hline \multicolumn{10}{|c|}{ Persianovskaya Reserved Steppe } \\
\hline$A_{d}$ & $0-10$ & - & 16.4 & 27.0 & 4.3 & 15.2 & 37.1 & 56.6 & 43.4 \\
\hline A & $10-45$ & - & 9.7 & 38.6 & 9.3 & 12.7 & 29.7 & 51.7 & 48.3 \\
\hline $\mathrm{AB}$ & $45-75$ & - & 11.9 & 37.2 & 10.1 & 14.3 & 26.5 & 50.9 & 49.1 \\
\hline B & $75-90$ & - & 12.4 & 36.7 & 11.2 & 16.4 & 23.3 & 50.9 & 49.1 \\
\hline $\mathrm{BC}$ & $90-125$ & - & 14.9 & 34.0 & 11.5 & 15.6 & 24.0 & 51.1 & 48.9 \\
\hline \multicolumn{10}{|c|}{ Reserved Fallow land "Priazovskaya Steppe" } \\
\hline $\mathrm{A}_{\mathrm{d}}$ & $0-11$ & 1.7 & 26.3 & 39.1 & 9.4 & 12.7 & 10.8 & 32.9 & 67.1 \\
\hline A & $11-28$ & 1.0 & 26.3 & 34.6 & 11.7 & 12.2 & 14.2 & 38.1 & 61.9 \\
\hline $\mathrm{AB}$ & $28-48$ & 1.1 & 24.4 & 37.8 & 8.1 & 12.8 & 15.8 & 36.7 & 63.3 \\
\hline B & $48-70$ & 0.9 & 25.8 & 36.4 & 7.3 & 10.6 & 19.0 & 36.9 & 63.1 \\
\hline $\mathrm{BC}$ & $70-120$ & 0.6 & 25.2 & 35.8 & 6.4 & 8.9 & 23.1 & 38.4 & 61.6 \\
\hline
\end{tabular}

The largest reserve of organic matter $(280.8 \mathrm{t} / \mathrm{ha})$ is found in the Persianovskaya Reserved Steppe, which corresponds to a very high level of provision (Orlov et al., 2005). The chernozems of the Botanical Garden and the Reserved Fallow land "Priazovskaya Steppe" are characterized by medium reserves of organic matter (Table 1).

Varied amounts of free carbonates occur at different depths of the $2 \mathrm{~m}$ thick soil layer. Carbonate mycelium is clearly defined at a depth of 20-30 cm below the effervescence line to the appearance level of $\mathrm{CaCO}_{3}$ nodules (Fig. 2). The carbonate content varies from 0.4 to $11.3 \%$ increasing with depth (Table 2). The highest content of carbonates along the soil profile is characterized Haplic Chernozem of the Reserved Fallow land.

The study of particle size distribution in the Haplic Chernozems of all SPNAs revealed an elevated content $(27-47 \%)$ of the large clay fraction (the particle with size $0.05-0.01 \mathrm{~mm}$ ) (Table 4). The mineralogy of this fraction little differs from that of the sand fraction, because it consists of fragments of primary minerals (quartz and feldspars). The large clay fraction is nonplastic; it swells slightly and has a low water capacity.

In accordance with the predominant fractions, the studied chernozems are classified as follows: The chernozem of the Botanical Garden is silty-large clayey; the chernozem of the Persianovskaya Reserved Steppe is large-clayey-silty and the chernozem of the Reserved Fallow land is large-clayey-small-sandy in texture.
According to the content of clay (the particle with size $<0.01 \mathrm{~mm}$ ), the studied chernozems of the Persianovskaya Reserved Steppe and Botanical Garden are classified as heavy loam and the chernozem of the Reserved Fallow land is medium loam.

The results of elements contents in the studied soils showed (Table 5), that the $\mathrm{SiO}_{2}, \mathrm{Al}_{2} \mathrm{O}_{3}$ and $\mathrm{Fe}_{2} \mathrm{O}_{3}$ contents are uniform under soil profiles. Such elemental distribution is typical to chernozemic type of soilformation. The microelements content is insignificant and decreases with the depth gradually. The $\mathrm{CaO}$ and $\mathrm{MgO}$ content increases down to the soil profile due to the increase of carbonates content.

\section{Discussion}

In accordance with the thickness of the humusaccumulative (A) and humus $(\mathrm{A}+\mathrm{B})$ horizons, the studied soils can be arranged in the following seriesHaplic Chernozem of the Persianovskaya Reserved Steppe >Haplic Chernozem of the Botanical Garden $>$ Haplic Chernozem of the Reserved Fallow land.

The lowest content of the organic matter is found in the chernozems of the Botanical Garden, which is explained by the shortest period of their fallowing ( 9 years) and mixed regime of reservation. Nowadays in Botanical garden hay harvesting is carried out which leads to loss of the organic matter. The analysis of organic 
matter content in Haplic Chernozems in Botanical Garden in different years showed, that the organic matter content decreased on $0.37 \%$ since 1953 to 2014 (Table 3). At present, the Haplic Chernozems in Botanical Garden are at the restoration stage (Kryshchenko et al., 2016). In the Haplic Chernozems of the Reserved Fallow land and Persianovskaya Reserved Steppe with the full reservation conditions since 1953 year no changes in the organic matter content were noted (Table 3). Consequently, the organic matter content in the soil is affected by both the duration and conditions of reservation.

The chernozems of the Persianovskaya Reserved Steppe and the Botanical Garden have relatively high contents of silt (the particle with size $<0.001$ ) (Table 4). The silt fractions of Haplic Chernozems contain four groups of clay minerals: kaolinite, chlorite, hydromica and smectite minerals (Kryshchenko et al., 2016). In the clay fraction (the particle with size 0.05-0.001) of the soils, the content of hydromicas increases by $10-19 \%$ compared to the clay fraction and that of smectites decreases. The chernozems of the Reserved Fallow land "Priazovskaya Steppe" are characterized by an elevated content of small sand (the particle with size 0.25-0.05), which explains the low level of soil fertility.
Haplic Chernozems are characterized by specific distributions of free carbonates in the form of carbonate mold along with common carbonate neoformations (beloglazka and veins) (Bezuglova and Yudina, 2006; Bezuglova and Tischenko, 2012; Gromakova et al., 2017; Minkina et al., 2008; 2010). Haplic Chernozems are frequently called micellar-calcareous chernozems. Carbonate mycelium consists of the most mobile carbonate material, ikaite (needle calcite) $\mathrm{CaCO}_{3} \cdot 6 \mathrm{H}_{2} \mathrm{O}$ (Valkov et al., 1982; Minkina et al., 2010). This mineral is predominant in the upper horizons of chernozems developed on loesses; calcite and dolomites also appear with depth. Carbonates are especially important in Haplic Chernozems, which have a one-layered alkaline vertical profile, in distinction from other Chernozems. The carbonate content is not a formal morphological feature; it reflects the specificity of aerohydrothermal conditions in these soils and the formation conditions of mobile chemical compounds. Mild winters, slight winter frosts, deep soil wetting, lasting warm periods and the alternation of downward and upward moisture fluxes result in a significant variation of carbonate migration along the soil profile and favor the development of micellar neoformations clearly observed on drying soil sections (Valkov et al., 1982).

Table 5: Elements contents of the Haplic Chernozems of the studied SPNAs

\begin{tabular}{|c|c|c|c|c|c|c|c|c|c|c|c|c|c|c|c|}
\hline \multirow[b]{3}{*}{ Elements } & \multicolumn{15}{|c|}{ Horizon, dept $(\mathrm{cm})$} \\
\hline & \multicolumn{5}{|c|}{$\begin{array}{l}\text { Botanical Garden of the Southern } \\
\text { Federal University }\end{array}$} & \multicolumn{5}{|c|}{ Persianovskaya Reserved Steppe } & \multicolumn{5}{|c|}{$\begin{array}{l}\text { Reserved Fallow land } \\
\text { "Priazovskaya Steppe" }\end{array}$} \\
\hline & $\begin{array}{l}\text { Ad, } \\
0-10\end{array}$ & $\begin{array}{l}\text { A, } \\
10-25 \\
\end{array}$ & $\begin{array}{l}\mathrm{AB} \\
25-60 \\
\end{array}$ & $\begin{array}{l}\text { Bca, } \\
60-80\end{array}$ & $\begin{array}{l}\mathrm{BC}, \\
80-95 \\
\end{array}$ & $\begin{array}{l}\text { Ad, } \\
0-10\end{array}$ & $\begin{array}{l}\text { A, } \\
10-45\end{array}$ & $\begin{array}{l}\mathrm{AB} \\
45-75\end{array}$ & $\begin{array}{l}\text { Bca, } \\
75-90\end{array}$ & $\begin{array}{l}\mathrm{BC}, \\
90-125\end{array}$ & $\begin{array}{l}\text { Ad, } \\
0-11 \\
\end{array}$ & $\begin{array}{l}\text { A, } \\
11-28\end{array}$ & $\begin{array}{l}\mathrm{AB} \\
28-48\end{array}$ & $\begin{array}{l}\text { Bca, } \\
48-70\end{array}$ & $\begin{array}{l}\mathrm{BC}, \\
70-120 \\
\end{array}$ \\
\hline \multirow[t]{2}{*}{$\mathrm{TiO}_{2}(\%)$} & 0.8 & 0.8 & 0.8 & 0.8 & 0.7 & 0.8 & 0.8 & 0.8 & 0.8 & 0.7 & 0.8 & 0.8 & 0.8 & 0.7 & 0.7 \\
\hline & \pm 0.1 & \pm 0.05 & \pm 0.1 & \pm 0.06 & \pm 0.03 & \pm 0.07 & \pm 0.05 & \pm 0.03 & \pm 0.08 & \pm 0.04 & \pm 0.06 & \pm 0.1 & \pm 0.03 & \pm 0.04 & \pm 0.05 \\
\hline \multirow[t]{2}{*}{$\mathrm{Fe}_{2} \mathrm{O}_{3}(\%)$} & 5.1 & 4.8 & 4.7 & 4.5 & 4.5 & 5.3 & 4.9 & 4.8 & 4.6 & 4.6 & 4.4 & 4.6 & 4.1 & 3.9 & 3.6 \\
\hline & \pm 0.4 & \pm 0.3 & \pm 0.3 & \pm 0.1 & \pm 0.2 & \pm 0.4 & \pm 0.2 & \pm 0.3 & \pm 0.2 & \pm 0.1 & \pm 0.3 & \pm 0.4 & \pm 0.2 & \pm 0.3 & \pm 0.2 \\
\hline \multirow[t]{2}{*}{$\mathrm{Al}_{2} \mathrm{O}_{3}(\%)$} & 12.0 & 11.0 & 10.9 & 10.5 & 10.5 & 12.1 & 12.2 & 11.7 & 11.7 & 11.6 & 10.9 & 11.3 & 10.6 & 10.4 & 10.4 \\
\hline & \pm 0.9 & \pm 0.8 & \pm 1.1 & \pm 0.7 & \pm 0.6 & \pm 0.3 & \pm 1.0 & \pm 0.9 & \pm 1.4 & \pm 0.6 & \pm 1.1 & \pm 0.9 & \pm 1.2 & \pm 0.8 & \pm 1.7 \\
\hline \multirow[t]{2}{*}{$\mathrm{SiO}_{2}(\%)$} & 62.8 & 61.4 & 56.8 & 53.2 & 52.9 & 64.0 & 63.7 & 55.6 & 54.5 & 52.9 & 66.8 & 67.2 & 61.8 & 57.8 & 53.2 \\
\hline & \pm 7.4 & \pm 6.8 & \pm 4.6 & \pm 3.8 & \pm 3.7 & \pm 2.9 & \pm 4.8 & \pm 5.3 & \pm 7.1 & \pm 6.3 & \pm 4.9 & \pm 5.5 & \pm 9.0 & \pm 6.3 & \pm 3.9 \\
\hline \multirow[t]{2}{*}{$\mathrm{CaO}(\%)$} & 1.9 & 2.0 & 2.5 & 8.0 & 8.1 & 2.4 & 2.6 & 8.6 & 9.3 & 9.6 & 2.2 & 2.2 & 5.9 & 9.1 & 11.1 \\
\hline & \pm 0.3 & \pm 0.1 & \pm 0.2 & \pm 0.1 & \pm 0.3 & \pm 0.2 & \pm 0.3 & \pm 0.7 & \pm 0.6 & \pm 0.5 & \pm 0.1 & \pm 0.3 & \pm 0.5 & \pm 0.4 & \pm 0.9 \\
\hline \multirow[t]{2}{*}{$\mathrm{P}_{2} \mathrm{O}_{5}(\%)$} & 0.2 & $0.2 \pm$ & $0.1 \pm$ & $0.2 \pm$ & $0.1 \pm$ & $0.2 \pm$ & $0.2 \pm$ & $0.2 \pm$ & $0.2 \pm$ & $0.2 \pm$ & $0.1 \pm$ & $0.1 \pm$ & $0.1 \pm$ & $0.1 \pm$ & $0.1 \pm$ \\
\hline & \pm 0.01 & 0.03 & 0.01 & 0.02 & 0.02 & 0.04 & 0.02 & 0.01 & 0.01 & 0.01 & 0.02 & 0.01 & 0.03 & 0.01 & 0.02 \\
\hline \multirow[t]{2}{*}{$\mathrm{K}_{2} \mathrm{O}(\%)$} & 2.1 & 2.1 & 2.0 & 1.7 & 1.6 & 2.2 & 2.1 & 1.8 & 1.8 & 1.7 & 1.9 & 1.9 & 1.8 & 1.7 & 1.6 \\
\hline & \pm 0.1 & \pm 0.2 & \pm 0.1 & \pm 0.07 & \pm 0.1 & \pm 0.2 & \pm 0.09 & \pm 0.1 & \pm 0.05 & \pm 0.1 & \pm 0.1 & \pm 0.2 & \pm 0.1 & \pm 0.05 & \pm 0.08 \\
\hline \multirow[t]{2}{*}{$\mathrm{MgO}(\%)$} & 1.1 & 1.2 & 1.2 & 2.0 & 2.4 & 1.4 & 1.4 & 2.2 & 2.3 & 2.4 & 1.2 & 1.2 & 1.7 & 2.2 & 2.2 \\
\hline & \pm 0.08 & \pm 0.1 & \pm 0.2 & \pm 0.1 & \pm 0.09 & \pm 0.07 & \pm 0.1 & \pm 0.1 & \pm 0.07 & \pm 0.2 & \pm 0.07 & \pm 0.06 & \pm 0.07 & \pm 0.1 & \pm 0.09 \\
\hline \multirow[t]{2}{*}{$\mathrm{Cu}\left(\mathrm{mg} \mathrm{kg}^{-1}\right)$} & 53.3 & 51.4 & 53.2 & 53.9 & 54.1 & 50.5 & 43.8 & 42.8 & 47.7 & 48.1 & 45.3 & 48.7 & 49.0 & 52.3 & 50.7 \\
\hline & \pm 4.7 & \pm 6.0 & \pm 4.5 & \pm 3.2 & \pm 4.0 & \pm 5.2 & \pm 3.6 & \pm 2.0 & \pm 3.1 & \pm 5.4 & \pm 4.3 & \pm 7.1 & \pm 6.3 & \pm 3.9 & \pm 7.2 \\
\hline \multirow[t]{2}{*}{$\mathrm{Zn}\left(\mathrm{mg} \mathrm{kg}^{-1}\right)$} & 92.3 & 83.0 & 78.2 & 71.2 & 69.0 & 78.1 & 71.3 & 74.8 & 70.6 & 68.8 & 74.0 & 68.7 & 61.9 & 64.6 & 62.3 \\
\hline & \pm 12.4 & \pm 10.3 & \pm 8.7 & \pm 5.1 & \pm 3.2 & \pm 6.1 & \pm 8.2 & \pm 4.4 & \pm 7.3 & \pm 6.0 & \pm 8.1 & \pm 4.7 & \pm 7.0 & \pm 5.6 & \pm 3.9 \\
\hline \multirow[t]{2}{*}{$\mathrm{Pb}\left(\mathrm{mg} \mathrm{kg}^{-1}\right)$} & 40.0 & 34.7 & 28.3 & 21.0 & 20.5 & 29.3 & 22.2 & 12.1 & 13.6 & 13.1 & 27.9 & 30.2 & 26.8 & 21.3 & 20.9 \\
\hline & \pm 3.5 & \pm 2.1 & \pm 2.4 & \pm 1.7 & \pm 1.2 & \pm 2.3 & \pm 1.6 & \pm 0.8 & \pm 1.4 & \pm 1.1 & \pm 1.8 & \pm 2.6 & \pm 1.5 & \pm 2.1 & \pm 1.6 \\
\hline \multirow[t]{2}{*}{$\mathrm{Cr}\left(\mathrm{mg} \mathrm{kg}^{-1}\right)$} & 126.1 & 106.9 & 117.6 & 109.9 & 107.1 & 105.3 & 90.5 & 95.2 & 81.3 & 79.5 & 120.8 & 105.4 & 98.8 & 102.6 & 104.2 \\
\hline & \pm 15.8 & \pm 11.0 & \pm 13.1 & \pm 12.3 & \pm 8.5 & \pm 7.4 & \pm 7.7 & \pm 5.2 & \pm 8.4 & \pm 6.3 & \pm 14.3 & \pm 13.0 & \pm 7.4 & \pm 11.0 & \pm 12.4 \\
\hline \multirow[t]{2}{*}{$\operatorname{Mn}\left(\mathrm{mg} \mathrm{kg}^{-1}\right)$} & 848.7 & 818.8 & 845.6 & 642.9 & 623.7 & 860.1 & 800.6 & 751.4 & 747.4 & 745.9 & 782.9 & 787.4 & 685.3 & 582.9 & 563.9 \\
\hline & \pm 42.7 & \pm 38.4 & \pm 29.3 & \pm 24.2 & \pm 32.4 & \pm 46.2 & \pm 36.9 & \pm 30.1 & \pm 37.8 & \pm 26.9 & \pm 40.1 & \pm 31.7 & \pm 26.3 & \pm 38.2 & \pm 19.8 \\
\hline \multirow[t]{2}{*}{$\mathrm{Ni}\left(\mathrm{mg} \mathrm{kg}^{-1}\right)$} & 50.0 & 52.4 & 51.7 & 51.9 & 53.3 & 39.3 & 42.5 & 35.9 & 35.5 & 34.5 & 41.2 & 48.0 & 46.4 & 46.2 & 46.7 \\
\hline & \pm 2.6 & \pm 4.2 & \pm 3.9 & \pm 1.8 & \pm 4.0 & \pm 2.5 & \pm 3.9 & \pm 1.5 & \pm 2.8 & \pm 4.1 & \pm 2.7 & \pm 5.2 & \pm 2.6 & \pm 4.2 & \pm 2.5 \\
\hline
\end{tabular}


The analysis of element content in the studied soils showed some differences in the distribution of elements throughout the soil profile of the chernozems of different SPNAs.

The contents of $\mathrm{MnO}, \mathrm{Fe}_{2} \mathrm{O}_{3}, \mathrm{Zn}$ and $\mathrm{Pb}$ in the Haplic Chernozem of Reserved Fallow land "Priazovskaya Steppe" is lower than in the Persianovskaya Reserved Steppe and the Botanical Garden by 1.1-1.3 times, which can be due to the differences in the texture and humus (organic matter) status parameters of the soils (Table 5). An increase in the content of copper down the profile of Haplic Chernozem in the Reserved Fallow land "Priazovskaya Steppe" and the Botanical Garden is noteworthy, which is related to the chemical composition of heavy loess-like loams. Protasova and Shcherbakov (2004) found that these parent rocks are characterized by an elevated content of copper, in contrast to fluvioglacial rocks and light loess-like loams. Such are the regional biogeochemical features of the soil microelement composition in Rostov region and of the mineralogical composition of the parent rocks. The yellow-brown loess-like loams and clays of the Pre-Caucasian Plain inherited the stable minerals of the initial rocks with the typical microelement composition of the minerals (Kryshchenko et al., 2016; Minkina et al., 2017a). The lighter texture of the Haplic Chernozem in the Reserved Fallow land "Priazovskaya Steppe" is due to the increased content of $\mathrm{SiO}_{2}$ compared to the other soils under study. No exceedance of Maximum Permissible Concentrations (MPCs) (MPCs, $\mathrm{mg} \mathrm{kg}^{-1}$ for: $\mathrm{Cu}-55, \mathrm{Zn}$ - 100, Pb - 32, Cr - 90, Mn - 1500, Ni - 85 (MPC, 2006)) for heavy metals is found in the Reserved Fallow land "Priazovskaya Steppe".

The highest contents of macro- and microelements are typical for the Haplic Chernozem of the Persianovskaya Reserved Steppe, which is due to the highest content of organic matter (Table 2). The contents of copper and lead reach the MPCs for these elements, which could be due to the effect of the Novocherkassk power station located at 10 $\mathrm{km}$, one of the largest power plants of Russia.

Lower contents of $\mathrm{CaO}$ and $\mathrm{MgO}$ are found in the Haplic Chernozems of the Botanical Garden than in the Persianovskaya Reserved Steppe and Reserved Fallow land (Table 5), which is related to the intensive leaching of carbonates. In the chernozem of the Botanical Garden located in the center of the Rostov-on-Don city, an exceedance of MPC is recorded only for $\mathrm{Pb}$, which is due to emissions from industrial plants and motor vehicles.

\section{Conclusion}

The highest content and reserve of organic matter, as well as the thicknesses of the humus-accumulative (A) and humus $(\mathrm{A}+\mathrm{B})$ horizons, are found in the Haplic Chernozem of the Persianovskaya Reserved Steppe, which is due to the long period (about 115 years) and regime of reservation.

The comparison of the humus (organic matter) status of soils in different years of studies shows that the content of organic matter in the Haplic Chernozem of the Botanical Garden decreased from $4.42 \%$ in 1953 to $4.05 \%$ in 2014. In the chernozems of the Reserved Fallow land and Persianovskaya Reserved Steppe, the content of organic matter remained stable from 1953.

Elevated content $(27-47 \%)$ of the large clay fraction (the particle with size $0.05-0.01 \mathrm{~mm}$ ) is revealed in all chernozems of the studied SPNAs. The chernozems of the Persianovskaya Reserved Steppe and the Botanical Garden are characterized by higher contents of silt (the particle with size $<0.001$ ) and the chernozems of the Reserved Fallow land "Priazovskaya Steppe" have an elevated content of small sand (the particle with size 0.25-0.05), which explains their lower fertility level.

Haplic Chernozems of the SPNAs have a one-layered alkaline vertical profile increasing $\mathrm{CaCO}_{3}$ content with depth from 0.4 to $11.3 \%$. Specificity of aero hydrothermal conditions of these soils formation leads in a significant variation of carbonate migration along the soil profile and favor the development of micellar neoformations.

According to the supply with macro- and micronutrients, the Haplic Chernozem of the studied SPNAs can be arranged in the following series: Persianovskaya Reserved Steppe $>$ Botanical Garden $>$ Reserved Fallow land "Priazovskaya Steppe". The content of $\mathrm{SiO}_{2}$ in the Haplic Chernozem of the Reserved Fallow land is higher than in the other SPNAs, which is due to the lighter texture. The Haplic Chernozems in the studies SPNAs of the Lower Don basin are uncontaminated with heavy metals. An insignificant exceedance of MPC for lead is noted in the soils of Botanical Garden located in the center of Rostov-on-Don city. An increase in the content of copper down the profile of Haplic Chernozems in all SPNAs is revealed, which is related to the chemical composition of parent rocks (loess-like loams).

The revealed features of elemental composition and particle size distribution in chernozems of different SPNAs should be taken into consideration at the selection of standard (control) plots during the monitoring of soil pollution in the Lower Don basin.

\section{Acknowledgment}

This work was supported by the Russian Science Foundation (no. 16-14-10217).

\section{Author's Contributions}

Saglara S. Mandzhieva: The head of the investigation, designed the research plan and organized 
the study, coordinated the data-analysis and contributed to the writing of the manuscript.

Ludmila Yu. Goncharova: Participated in allexperiments, coordinated the data-analysis andcontributed to the writing of the manuscript.

Abdulmalik A. Batukaev: Coordinated the dataanalysis and contributed to the writing of the manuscript.

Tatiana M. Minkina: Designed the research plan and organized the study, contributed to the writing of the manuscriptmanuscript and reviewing it critically for significant intellectual content.

Tatiana V. Bauer: Participated in all experiments, coordinated the data-analysis and contributed to the writing of the manuscript.

Aleksey K. Shertnev: Collected the field data, determined the heavy metals.

Victor A. Chaplygin: Analyzed the soil, performed the statistical analysis.

Svetlana N. Sushkova: Collected the field data and contributed to the writing of the manuscript.

Evgeniy V. Poluektov: Contributed in drafting the manuscript and reviewing it critically for significant intellectual content

Marina V. Burachevskaya: Contributed in drafting the manuscript and reviewing it critically for significant intellectual content

Marina N. Kozlova: Contributed to the technical work and data analysis

\section{Ethics}

This article is original and contains unpublished material. The corresponding author confirms that all of other authors have read and approved the manuscript and no ethical issues involved.

\section{References}

AMSS, 1990. Agrochemical methods of soil studies. Moscow, Russia.

Bezuglova, O.S. and N.V. Yudina, 2006. Interrelationship between the physical properties and the humus content of chernozems in the south of European Russia. Eurasian Soil Sci., 39: 187-194. DOI: $10.1134 / \mathrm{S} 1064229306020098$

Bezuglova, O.S. and S.A. Tischenko, 2012. The humus state of the soils of locally hydromorphic landscapes in the lower reaches of the Don River. Eurasian Soil Sci., 45: 132-140. DOI: $10.1134 / \mathrm{S} 1064229312020135$

Buzmakov, S.A. and P.Y. Sannikov, 2014. Landscape and biological diversity of protected areas network in Perm krai. Am. J. Environ. Sci., 10: 516-522. DOI: 10.3844 ajessp.2014.516.522
Cantu-Salazar, L., C.D.L. Orme, P.C. Rasmussen, T.M. Blackburn and K.J. Gaston, 2013. The performance of the global protected area system in capturing vertebrate geographic ranges. Biodiversity Conserv., 22: 1033-1047. DOI: $10.1007 / \mathrm{s} 10531-013-0467-7$

Dobrovolskii, G.V. and E.D. Nikitin, 2009. Red Book of Russian Soils: Objects of the Red Book and Red List of Especially Valuable Soils. 1st Edn., Moscow, Maks Press, ISBN-10: 978-5-31702-374-4, pp: 576.

Ervin, J., 2003. Protected area assessments in perspective. BioScience, 53: 819-822. DOI: 10.1641/00063568(2003)053[0819:PAAIP]2.0.CO;2

Gaston, K.J., K. Charman, S.F. Jackson, P.R. Armsworth and A. Bonn et al., 2006. The ecological effectiveness of protected areas: The United Kingdom. Biol. Conserv., 132: 76-87. DOI: $10.1016 /$ j.biocon.2006.03.013

Gaston, K.J., S.F. Jackson, L. Cantú-Salazar and G. Cruz-Piñón, 2008. The ecological performance of protected areas. Annual Rev. Ecol. Evolut. Systemat., 39: 93-113.

DOI: 10.1146/annurev.ecolsys.39.110707.173529

GOST 17.4.3.01, 1983. Nature protection. Soils. General requirements for sampling, Moscow (in Russian).

Gromakova, N., S. Mandzhieva, T. Minkina, O. Birukova and S. Kolesnikov et al., 2017. Effect of heavy metals on the enzymatic activity of Haplic Chernozem under model experimental conditions. OnLine J. Biol. Sci., 17: 143-150. DOI: $10.3844 /$ ojbsci.2017.143.150

IUSS, 2015. International soil classification system for naming soils and creating legends for soil maps. World Soil Resources Reports 106, IUSS Working Group WRB, FAO, Rome.

Kryshchenko, V.S., I.V. Zamulina, T.V. Rybyanets, N.E. Kravtsova and O.A. Biryukova et al., 2016. Dynamics of the microaggregate composition of chernozem in relation to changes in the content of organic matter. Eurasian Soil Sci., 49: 640-651. DOI: $10.1134 / \mathrm{S} 1064229316060041$

Minkina, T.M., D.L. Pinskii, T.V. Bauer, D.G. Nevidomskaya and S.S. Mandzhieva et al., 2017a. Sorption of $\mathrm{Cu}$ by chernozems in southern Russia. J. Geochem. Exp., 174: 107-112. DOI: $10.1016 /$ j.gexplo.2016.06.002

Minkina, T.M., G.V. Motusova, O.G. Nazarenko and S.S. Mandzhieva, 2010. Heavy Metal Compounds in Soil: Transformation Upon Soil Pollution and Ecological Significance. 1st Edn., Nova Science Publishers, Inc., New York, ISBN-10: 978-1-60876-466-2, pp: 189. 
Minkina, T.M., G.V. Motuzova, O.G. Nazarenko, V.S. Kryshchenko and S.S. Mandzhieva, 2008. Forms of heavy metal compounds in soils of the steppe zone. Eurasian Soil Sci., 41: 708-716. DOI: $10.1134 / \mathrm{S} 1064229308070053$

Minkina, T.M., D.L., Pinskii, I.V. Zamulina, D.G. Nevidomskaya and G. Gülser et al., $2017 \mathrm{~b}$. Chemical contamination of calcic chernozem as a transformation factor of its physicochemical properties. J. Soils Sediments. DOI: $10.1007 / \mathrm{s} 11368-017-1713-5$

MPC, 2006. Maximum permissible concentrations of chemical substances in soil. Hygienic standards GN 2.1.7.2041-06, Governmental Federal Center of Hygiene and Epidemiology, Moscow, (in Russian).

Orlov, D.A. and L.A. Grishina, 1981. Laboratory manual on humus chemistry. Moscow State University, Moscow(in Russian).

Orlov, D.S., L.K. Sadovnikova and N.I. Sukhanova, 2005. Soil chemistry. Moscow, (in Russian).

Protasova, N.A. and A.P. Shcherbakov, 2004. Microelemental composition of zonal soils in the central chernozemic region. Eurasian Soil Sci., 37: 40-48.
SPNA, 1995. Federal law on specially protected natural areas no 33. Moscow, Russia

UNLPA, 1998. United nations list of protected areas. IUCN, Gland, Switzerland and Cambridge, UK and UNEP_WCMC, Cambridge, UK.

UNLPA, 2003. United nations list of protected areas. IUCN, Gland, Switzerland and Cambridge, UK and UNEP_WCMC, Cambridge, UK, Thanet Press Ltd, UK.

Vadyunina, A.F. and Z.A. Korchagina, 1973. Methods of Studying the Physical Properties of Soils and Sediments. 1st Edn., Vysshaya Shkola, Moscow, pp: 416.

Valkov, V.F., G.G. Klimenko and V.S. Kryshichenko, 1982. Comparative description of the ordinary and southern chernozems of the lower don. Soviet Soil Sci., 12: 487-495

Vorob'eva, L.A., 2006. Theory and Practice of the Chemical Analysis of Soils. 1st Edn., GEOS, Moscow, ISBN-10: 5-89118-344-7, pp: 400.

Walkley, A., Black, I.A., 1934. An examination of Degtjareff method for determining soil organic matter and a proposed modification of the chromic acid titration method. Soil Sci., 37:29-37. 